\title{
Medieval and Modern The Prayer of a Medieval Noblewoman
}

by Mervyn Duffy SM

Theology tends to focus on clergy and religious. This lecture goes against that trend by considering the private devotions of a lay woman as they are revealed by her Book of Hours. Within that book we will focus on a series of images from a week of prayer entitled "The Hours of the Mercy of God".

$\mathrm{I}$ am going to begin this talk with a book recommendation. Now, I am no relation to the author-Duffy is a not uncommon name-but I have been lectured by him. Eamon Duffy's book is a wonderful introduction to the significance of Books of Hours or Primers. They were a major medieval status symbol. They also became family heirlooms with birth details and the like being recorded in them as well as pious additions and requests for prayers. Hence the title of his work "Marking the Hours"-he studied Primers that had been 'defaced' attempting to get into the minds of their users. $\mathrm{He}$ described this book as "a tribute to scribbles, and attempt to trace a history written, quite literally. in the margins." Eamon's attempts to get images of pages with marginalia did confuse some librarians. One queried the folio numbers he had listed for photography asking 'but why did someone scribble on them anyway?' When he explained that these were catholic books being censored by Tudor Protestants, she paused for thought and then commented tersely: 'well, I only hope they were their own, and not borrowed from a library'!

But that is Eamon's book-I want to talk about a Prayer Book. I'll begin in the traditional fashion:

Once upon a time there lived a beautiful and pious duchess... 

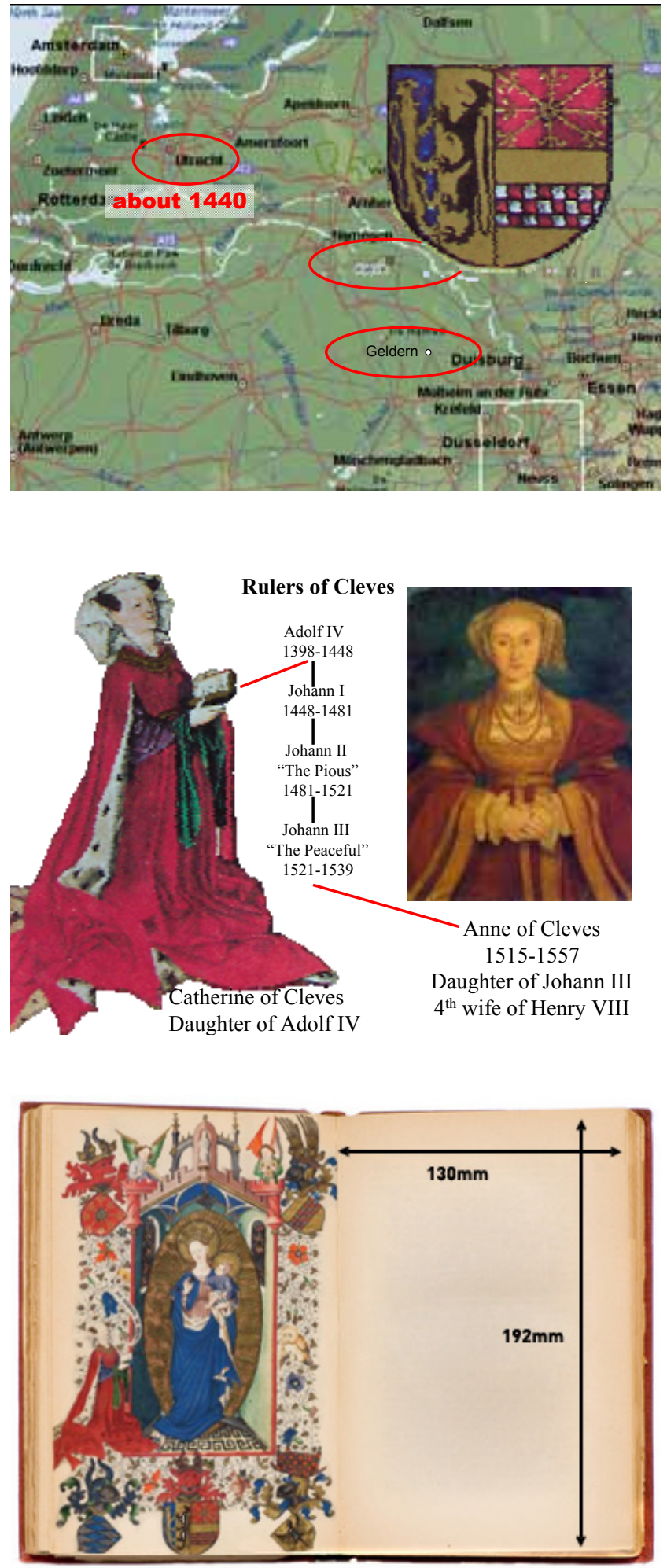

\section{The Rhine Valley.}

Well, the time was the 1400 s and the place was the Rhine Valley. The beautiful lady was called Catherine, the daughter of Adolph of Cleves. It is now called Kleve. In 1431 she married Duke Arnold of Guelders, his city is now called Geldern. About 1440, probably in Utrecht but maybe in Guelders, an anonymous artist produced for her a prayer book. It would have taken several years to illuminate. It is one of the most important of the medieval illuminated manuscripts, one of the richest books ever made.

Catherine is NOT Anne of Cleves.

Some of you will be sitting there saying "Isn't this the Flanders' Mare that married Henry VIII?" and the answer is "No. This is her great-great-aunt."

\section{Catherine of Cleves kneeling before the Virgin and Child.}

Her book of hours contains hundreds of miniature masterpieces. Each page measures 192 $\mathrm{mm}$ by $130 \mathrm{~mm}$ (or seven and half by five inches.) We are seeing the pictures far larger than Catherine ever did. She would have had to peer at them very closely. People of her time took great delight in delicate, beautiful miniatures. She'd probably be horrified to see them enlarged like this.

The artist was most likely a man, but the work is shaped by the taste and piety of the noble lady for which it was made. We are not just looking at art, we see Catherine at prayer. The images she uses to help her pray, enable us to glimpse something of her faith, and therefore shed light on our own.

The opening image of the work, shows Catherine at prayer, probably in her own chapel. 

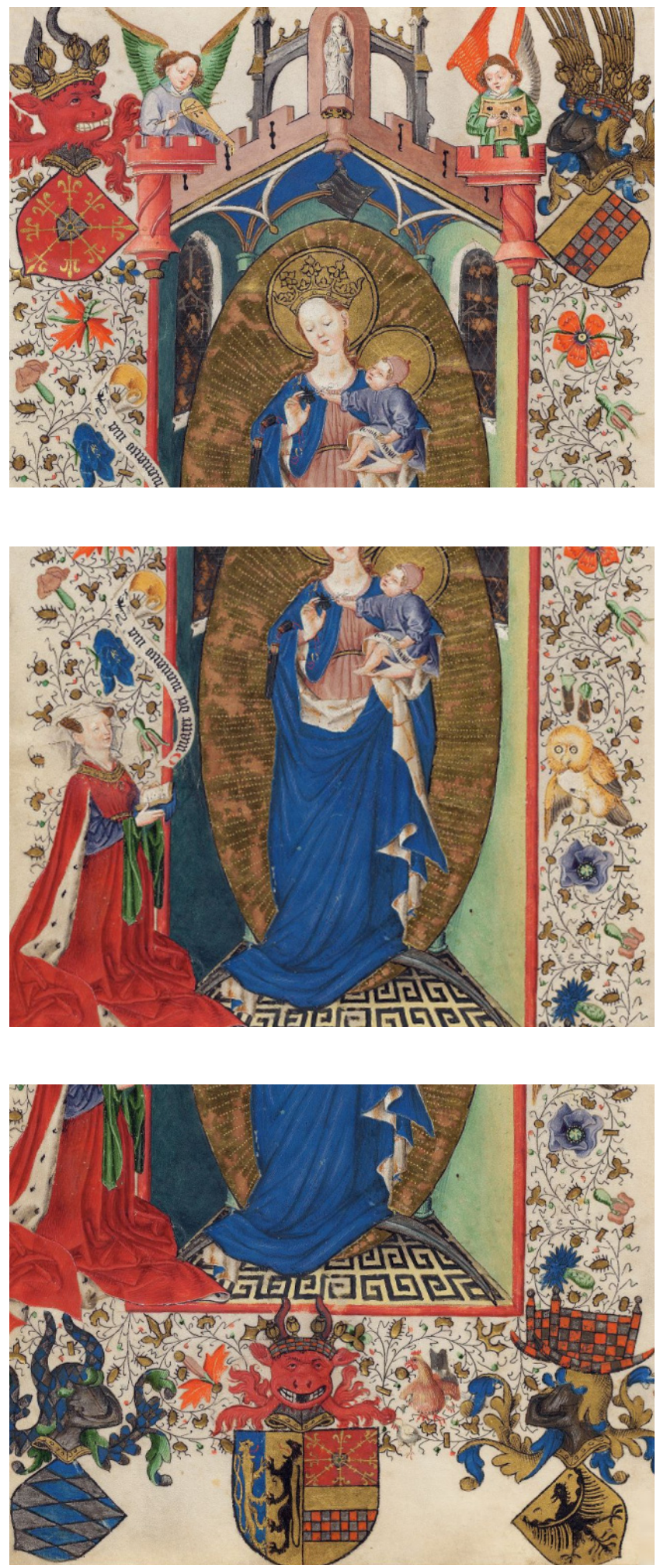

\section{Top of chapel.}

The chapel is surmounted by flying buttresses, crenellations, two turrets with music-making angels and, in the central niche, a statue in a gesture of benediction, holding a gold object (a church?) in its other arm. The statue may represent Saint Nicholas who was patron saint of the castle chapel at Cleves.

The shields are of Catherine's ancestors.

\section{Middle of picture of Catherine and Virgin.}

The crowned Virgin is holding her Child and an ink bottle into which He dips His pen. Across His lap lies an illegible scroll, and an empty scroll case hangs over the arm of the Virgin. Both figures, encompassed by a gold mandorla, Catherine kneels at the Virgin's right with this book open in her hands, and a banderole inscribed 0 mater dei memento mei. Facing Catherine in the opposite border is an owl. I think the artist is commenting subtly on the wisdom of what she is doing.

Bottom of picture of Catherine and Virgin.

The Virgin is standing on a thin, upturned crescent moon. In the border are the arms of Catherine as Duchess of Guelders and those of two more of her ancestors. 


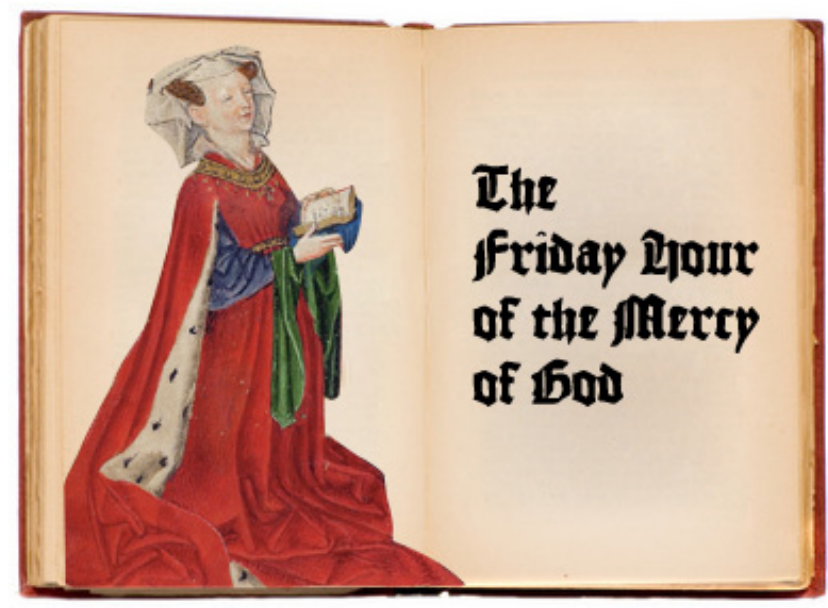

\section{frull page pirture}

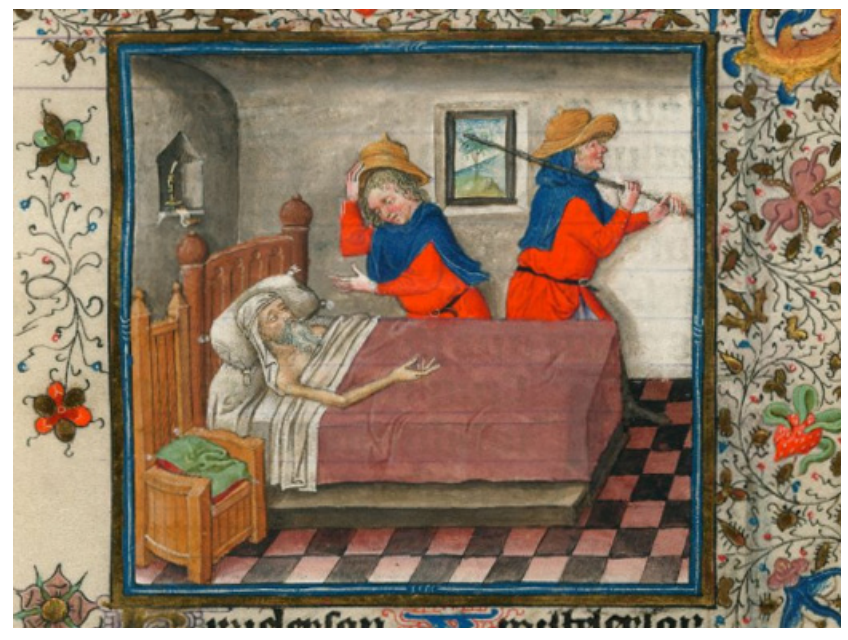

\section{The Hours of Catherine of Cleves.}

What is a book of hours? It is the prayer book of a lay person. The contents of the Liturgy of the Hours prayed by priests and religious was determined by Church law. Lay people were far freer in what prayers and devotions they might choose to follow. Catherine instructs her artist to prepare for her all the standard prayers of the day.

One feature of Catherine's book of hours is unusual. The Mercy of God is not rare as a theme in art, but the symbols associated with it have been used in the Hours and Mass of the Cross. The genius painting this work does not want to repeat the way of the Cross and the Passion. Instead he goes beyond the scriptural and liturgical tradition and depicts the legend of the Mercy Tree.

\section{Full page commencement.}

The single copy of the Hours of Catherine of Cleves was divided in two by an unscrupulous book seller in the 1800s. Either at that time or earlier some of the pages went missing. We don't know what has become of the full page miniature which commenced this section. Perhaps it was the Tree of Knowledge or the Fall. The story as we have it begins abruptly with the Dying Adam.
The dying Adam dispatching Seth to paradise. The cadaverous Adam lies on his deathbed, speaking to his third son, Seth, who stands beside the bed and respectfully removes his straw hat. Seth appears a second time, as he leaves the bedside, with his hat on and a staff over his shoulder - and unusual example in this manuscript of "continuous narrative." In addition to the imposing bed, the furnishings of the shallow barrel-vaulted room include a chair beside the bed and candle resting on a small scroll in a niche above the headboard. A small landscape with a tree (perhaps symbolic of the Tree of Mercy?) may be seen through the window in the rear wall separating the two Seths. 

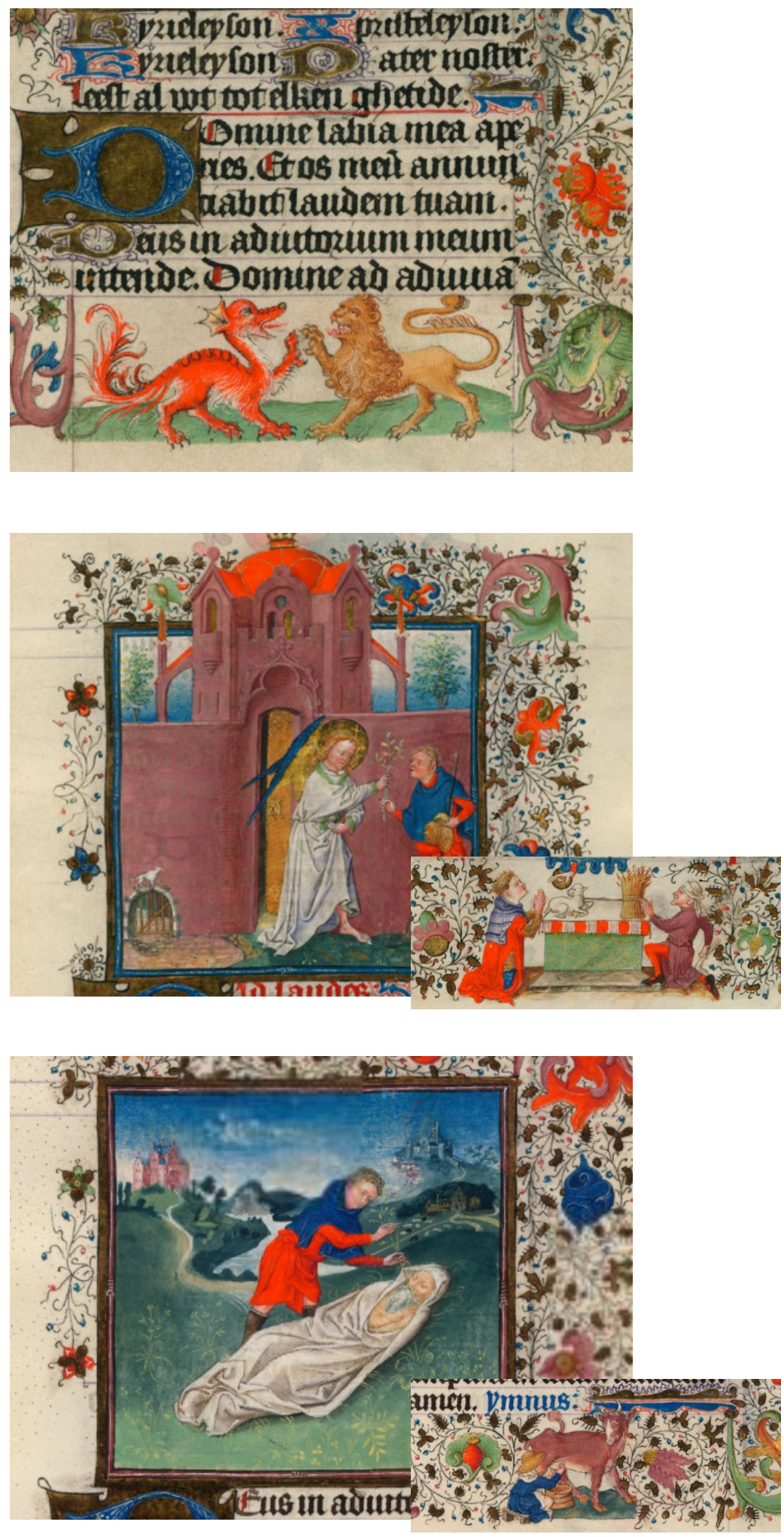

\section{The Dragon and the Lion.}

The pictures at the head of each page tell the story, which would have been familiar to Catherine. Yet she is to pray this book again and again so the artist has included images to tease her imagination. They are sometimes obviously connected with the story, others of them seem random. Mediaeval culture was preoccupied with parallels, analogies and symbols. Part of the fun and challenge of this prayer book for Catherine would have been in establishing connections between the foot of the page and the legend. Let's join her in trying to suggest plausible interpretations. What do you see? What do you think it means?

Catherine would have understood the language and symbolism of heraldry. These two figures are counter-passant with opposing fore-paws raised.

\section{The Archangel Michael giving Seth a Branch of the Tree of Mercy.}

The archangel Michael, having just emerged from the golden gate of Paradise, gives a branch to Seth. The two stand in front of the mauve-rose wall and a Gothic gate house to Paradise. Little can be seen of Paradise itself: two trees project above the wall, and through a sluice gate in the wall runs the water from one of the rivers of Paradise. The arched sluice gate, barred by a gold grating, resembles a water wheel turned by a small treading animal on the keystone.

In the lower border, Seth's older brothers, Abel and Cain, place offerings to God upon an altar.

\section{Seth planting the branch in the mouth of the dead Adam.}

The corpse of Adam, wrapped in a white shroud, has been laid on a hillside in a cool green landscape. Seth bends over the body and places the branch from Paradise in Adam's mouth.

In the lower border a seated woman with a straw hat milks a cow. 

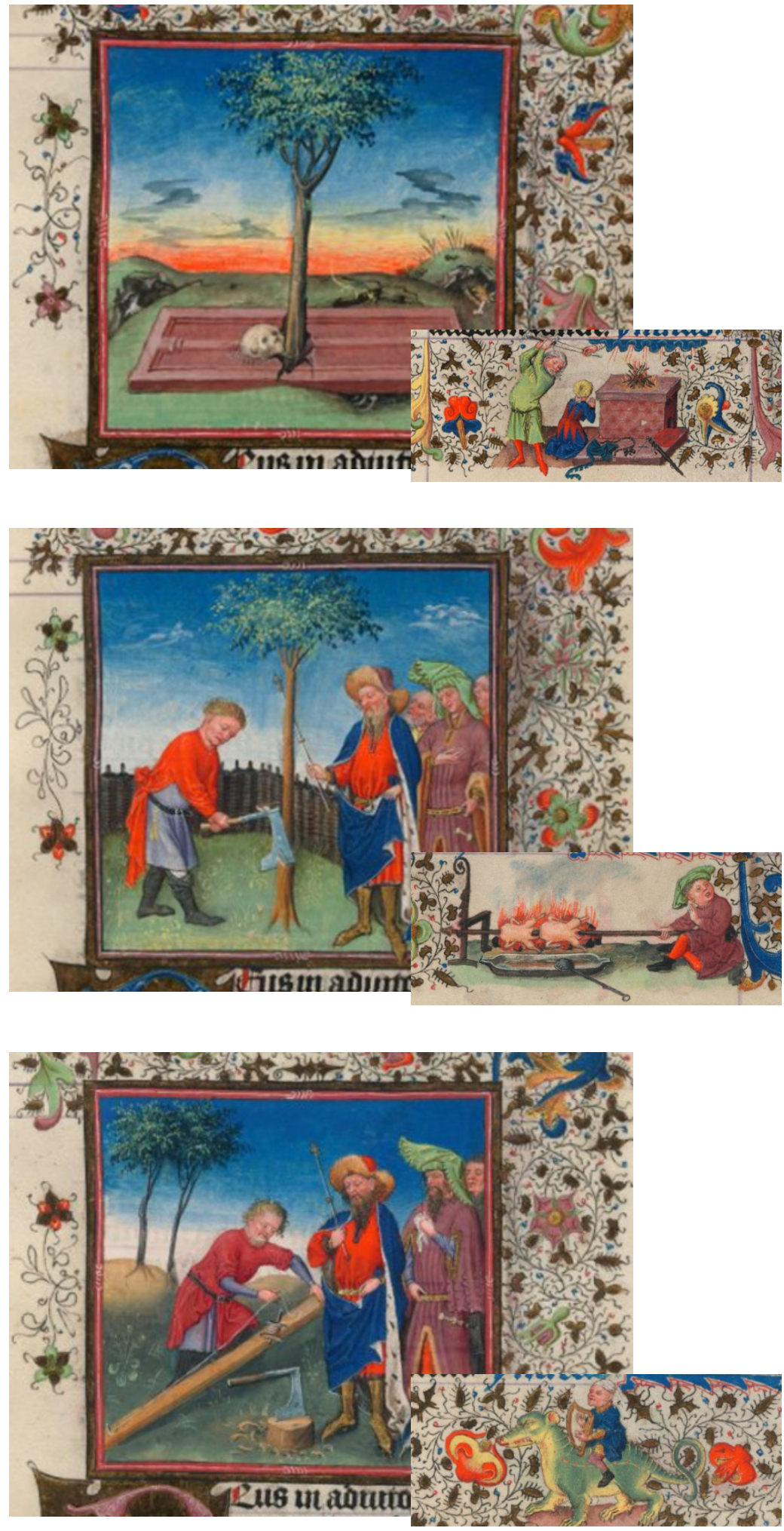

\section{Tree growing from Adam's grave.}

The tree has grown through a crack in the grave slab. At the base of the tree lies a skull, presumably Adam's, part of whose skeleton can be seen beneath the slab. The small green animal, probably a mouse, a frequent symbol of death and the destruction of time, is about the enter the grave. Behind, in his lair, a wolf-like animal gnaws upon a bone. The striking contrast of the green foreground and the vivid orange sunset sky is harmonized through the yellowish tones predominating in each. This scene is a rare early example of a "pure" landscape.

In the lower border the hand of God stays the sacrificial sword of Abraham raised to kill his son Isaac before a flaming altar. What does the sacrifice of Isaac have to do with the Mercy of God?

\section{Solomon ordering the tree cut down.}

Planning to use the tree for building his temple, Solomon commands that it be chopped down. The king and three members of his retinue stand at the right; Solomon touches the tree with his sceptre, while a carpenter at the left begins to fell it with his axe. The scene takes place in a space enclosed by a woven fence.

In the lower border a round-faced boy turns two animals, probably lambs or chickens, on an open-air spit with a fire behind and dripping-pan and ladle beneath.

\section{Measuring the timber.}

Having cut the tree and shaped the timber, the carpenter is measuring it with a piece of string, supervised by Solomon and two members of his retinue. The ax blade has been buried in the stump of a tree in the foreground; the enclosing woven fence has disappeared.

In the lower border a harp-playing dwarf rides a yellow and green "dragon." 


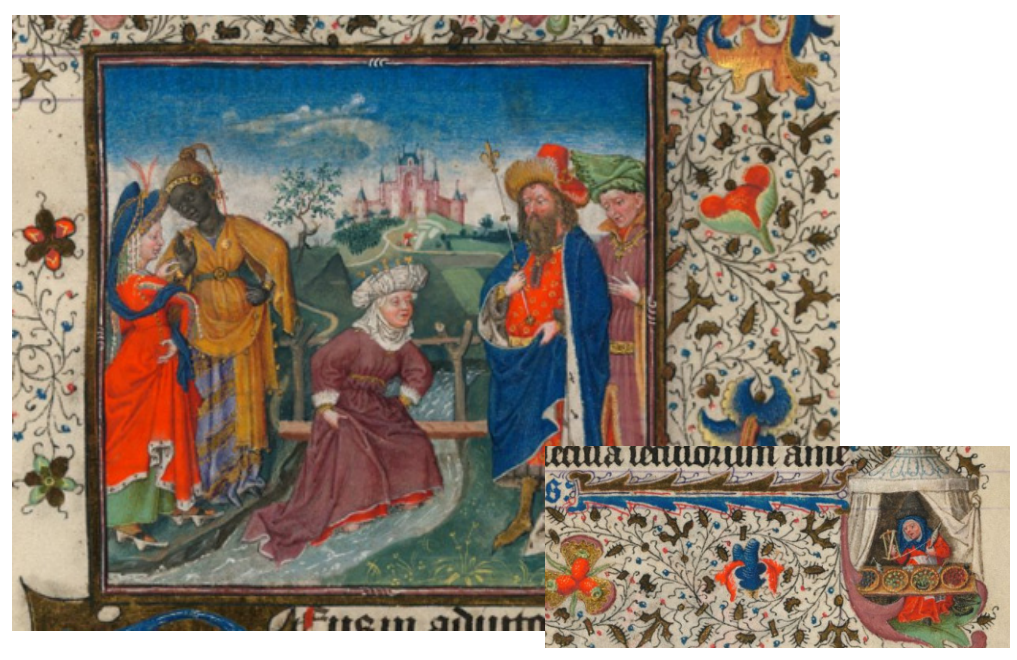

\section{Queen of Sheba fording a stream.}

When Solomon's carpenters found that they could not use the wood, which was always too long or too short for the Temple, they used it instead for a footbridge. The Queen of Sheba recognizing it as holy wood, refused to step on it and, according to one of the many versions of the story, waded through the stream - and according to the legend was cured of a malformation, namely "duck-feet" as a consequence. She is shown here holding up her long dress and fording the stream, while Solomon and one of his courtiers watch from the right bank. The courtier could be Duke Adolph of Cleves, father of Catherine, from the necklace worn by the Knights of Saint Anthony and from his likeness to Adolph's other portraits. On the left bank a Negro attendant of the queen, dressed in an exotic gold and purple costume, shows a piece of jewellery to a lady, presumably a member of the Queen of Sheba's entourage or the court of Solomon. The footbridge, made of the single timber and rough log railing, is visible behind the queen.

The border contains a woman spinning and displaying her garden produce before a conically tented market booth.

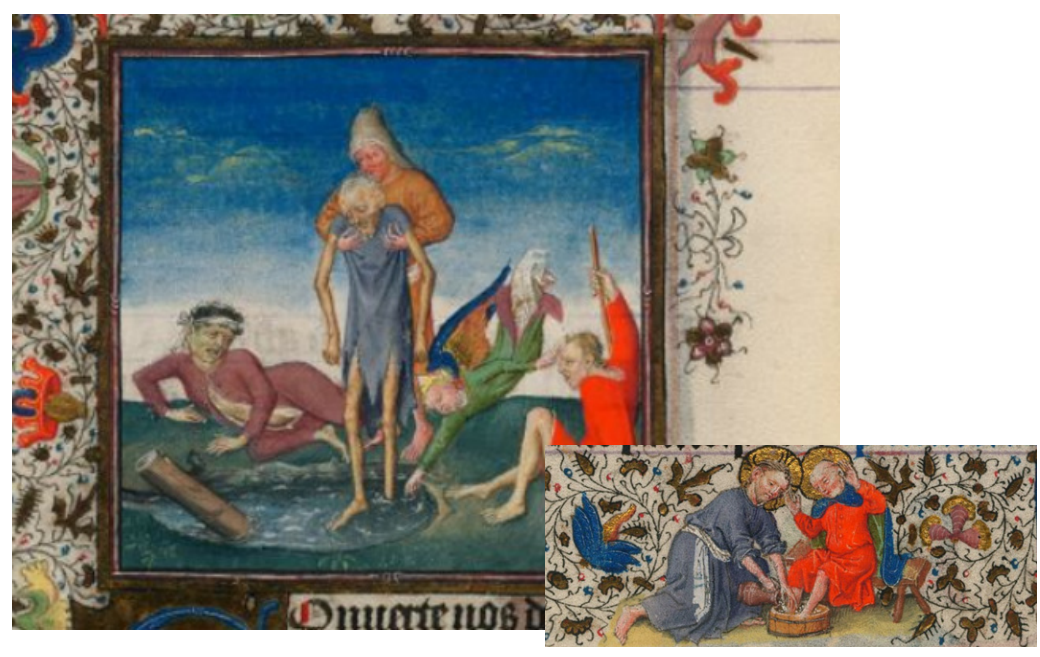

\section{Miracles of the Pool of Bethsaida.}

The healing powers of this pool, mentioned in the fifth chapter of Saint John's Gospel, are attributed to angel who occasionally stirs its waters. In the Middle Ages these powers were also explained by the presence in the pool of the wood of the Tree of Mercy, upon which, according to an ancient prophecy, the Kingdom of the Jews would come to its end. Fearing this prediction, Solomon had the wood buried, and the miraculous pool was formed by water welling up over the burial spot. In this scene the angel stirs the water, and the log (not the timber) floats in the pool. One lame man sits by the pool holding a staff; another lies beside the pool, while a third is lowered into the water by an attendant.

In the lower border, Christ, kneeling on the ground, washes the feet of Peter.

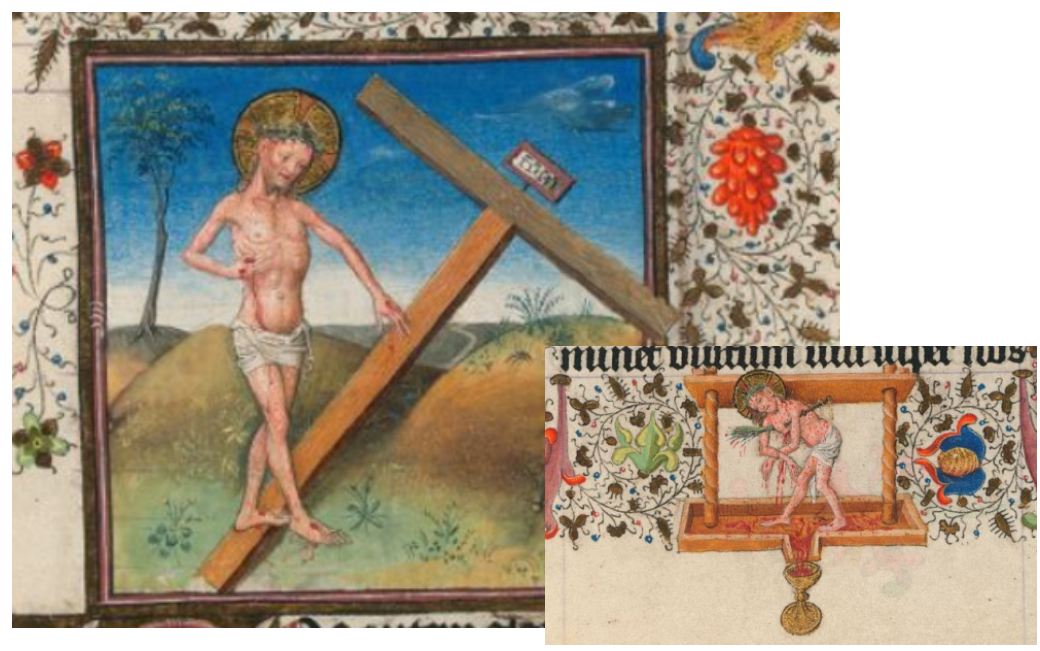

\section{Christ standing on the lowered cross.}

A second full-page miniature missing from this series on the legend of the cross must have faced this. I've substituted one from the Mass of the Cross.

Here Christ, bleeding from the wounds of His flagellation and crucifixion stands in triumph with one foot on the reclining cross. He is dressed only in a loincloth and wears His crown of thorns. No other figures appear; indeed, there is no sign whatever of any human habitation in the barren landscape. Rather than historical, the scene is allegorical.

In "Christ in the Winepress," another allegorical scene which appears in the lower border, Christ holds two whips from the flagellation under His arms, and the blood from his wounds runs through a trough into a golden chalice below. 

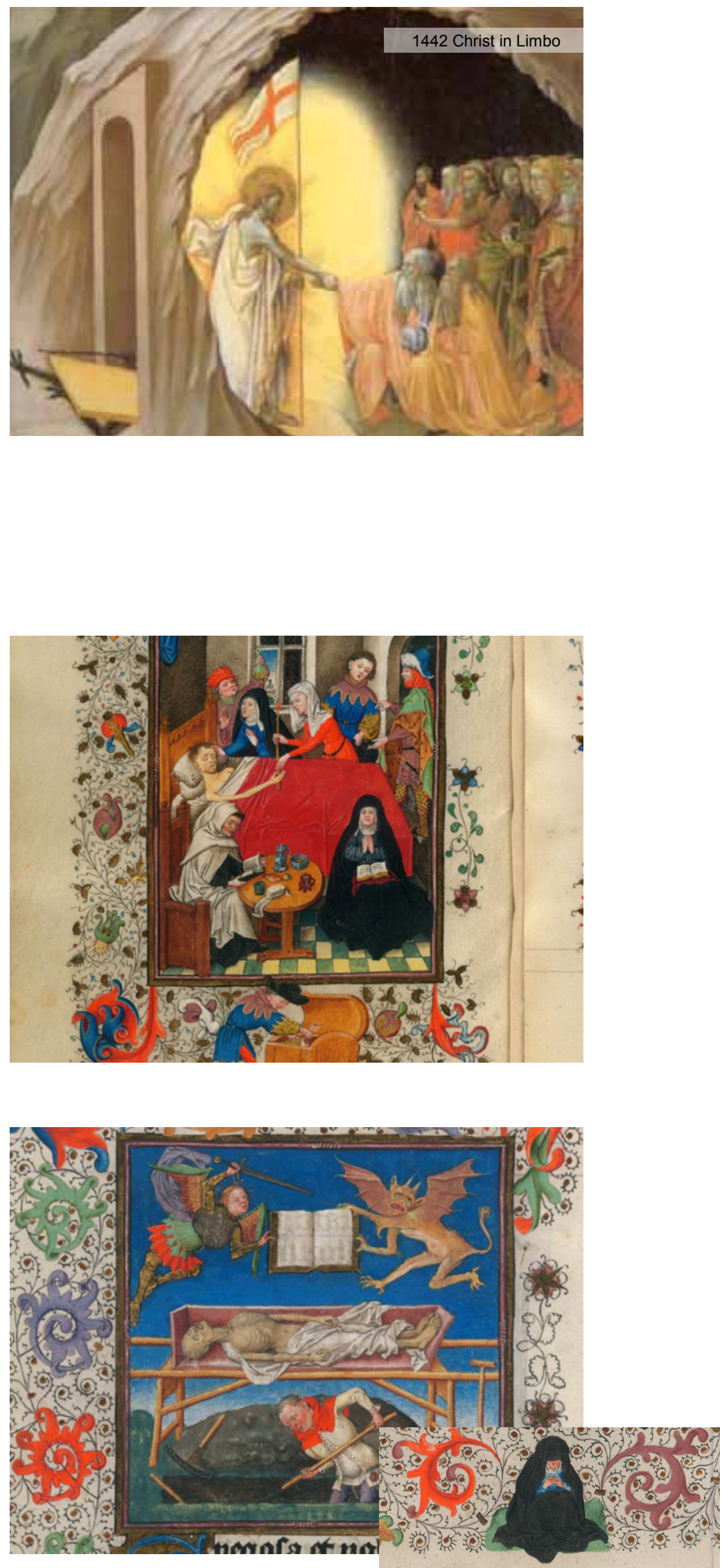

\section{Christ in Limbo.}

Just so we can finish the legend, here is a contemporary image of the event of Holy Saturday. This is often called "The Harrowing of Hell" of "The Descent Among the Dead." Until Christ opened the gates of Heaven no-one could be saved. The virtuous souls of the Old Testament went down to Hades, a kind of ante-chamber to Hell. In later thought this was termed Limbo. On Holy Saturday, before the Resurrection, Christ goes down to the devils domain, often carrying his cross, though here it is a banner. He bangs on the gates of Hell - you can see the devil had gone to answer - but then, impatient he knocks them flat, catching the devil unawares (you can see his chicken-foot sticking out from under the door as Christ strides over it.) The Christ, the fruit of the mercy tree, leads the virtuous souls out to heaven. They come forth in the order they went in, so the first to be saved is Adam. Christ grasps him by the wrist for this is not something that Adam can cooperate in, this is done by the Lord's power only. The mission that Seth began is finally accomplished by the power of the Mercy Tree.

\section{Deathbed.}

In a narrow room the bed of dying man divides the background figures from the two seated in the foreground: a cowled priest (?) reads at a table upon which stand numerous vessels, presumably for use in the Viaticum or Extreme Unction, while a black-garbed woman, probably the wife, prays over an open book of hours with its chemise (protective cover). Behind the bed are two women, one tending the dying man and the other helping him to hold a burning candle. A physician examines a urine specimen, and somewhat apart, stand a foppish companion and the mercenary heir, who appears again in the lower border taking money bags out of a coffer.

\section{Meditation on death.}

Guardian Angle and Demon Battling over a Corpse: The corpse, its winding sheet partly unwound, is laid out a coffin of which one side and the top have been removed. Its guardian angel richly dressed and brandishing a sword, struggles with a brown, winged demon for possession of a large, blank-paged, gilt-edged book. The coffin rests on a wooden rack beside the grave, which is being dug by a man with a long-handled shovel. A pick and spade are by the grave.

Below, in the border, a seated female mourner wrings her hands. 

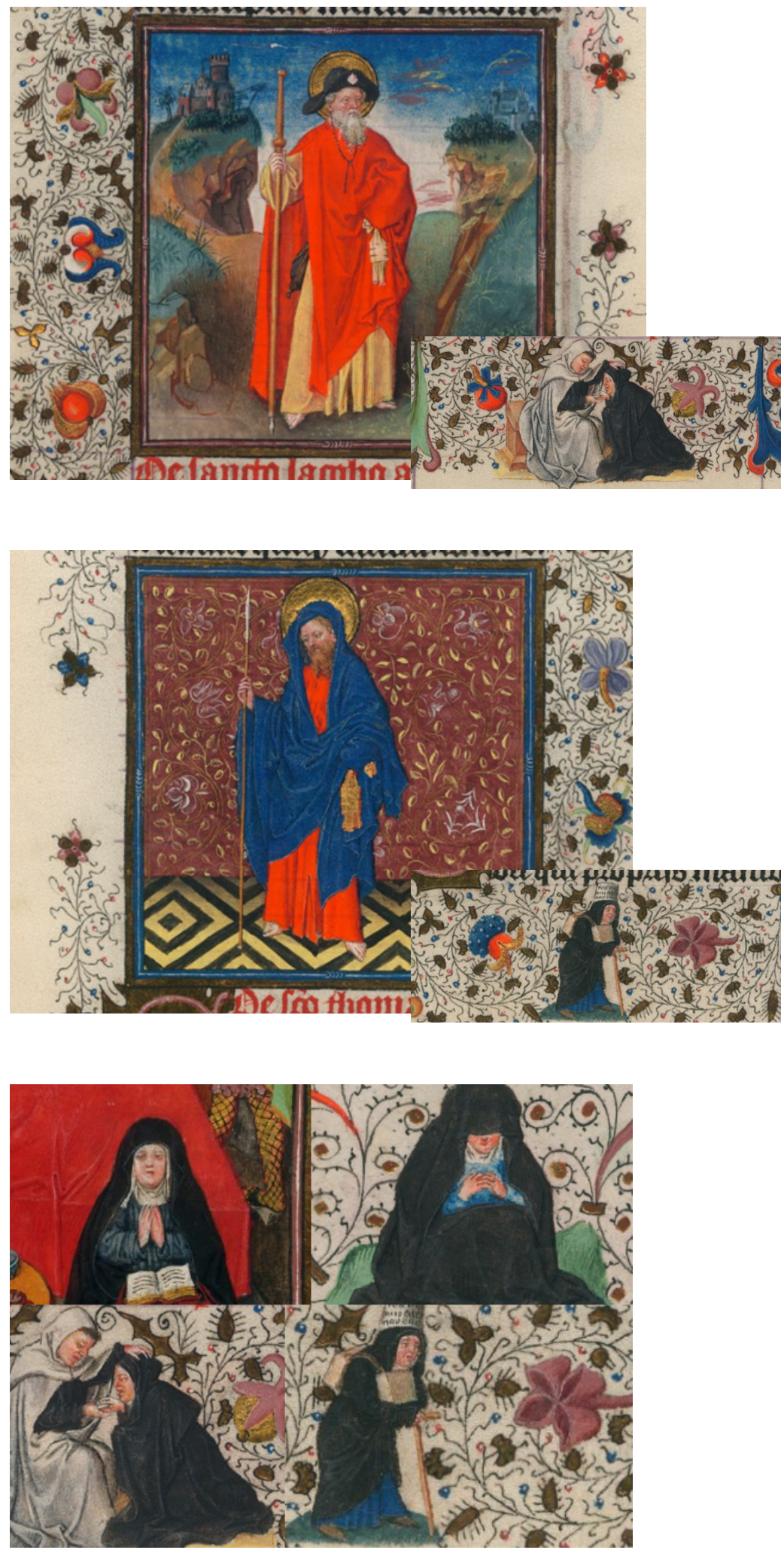

\section{St James Major.}

The saint stands in a landscape between two hills crowned by castles. He wears the apostle's cape and gown and broad-brimmed pilgrim's hat decorated with a shell. With pilgrim's pouch at his side, he carries a large pilgrim's staff and book bound in a loose envelope-binding.

At the bottom of the page, a weeping woman dressed in black is comforted by a cleric, caped and hooded in white, to whom she gives something, probably money. It seems likely that the grieving widow is about to leave on a pilgrimage, possibly to Compostela.

\section{St Thomas the Apostle.}

Thomas holds a lance and book in an envelope binding.

Below, in the border, a female pilgrim walks along with two rectangular packs strapped over her shoulders, and wearing a white drum-shaped "crown" bearing an illegible inscription. She is probably joined here with Saint Thomas because of his far-reaching travels.

The four women together.

It seems likely that Catherine in her meditating on this book of hours was meant to spot the similarity between these figures and to reflect on her own old age and possible widowhood. 

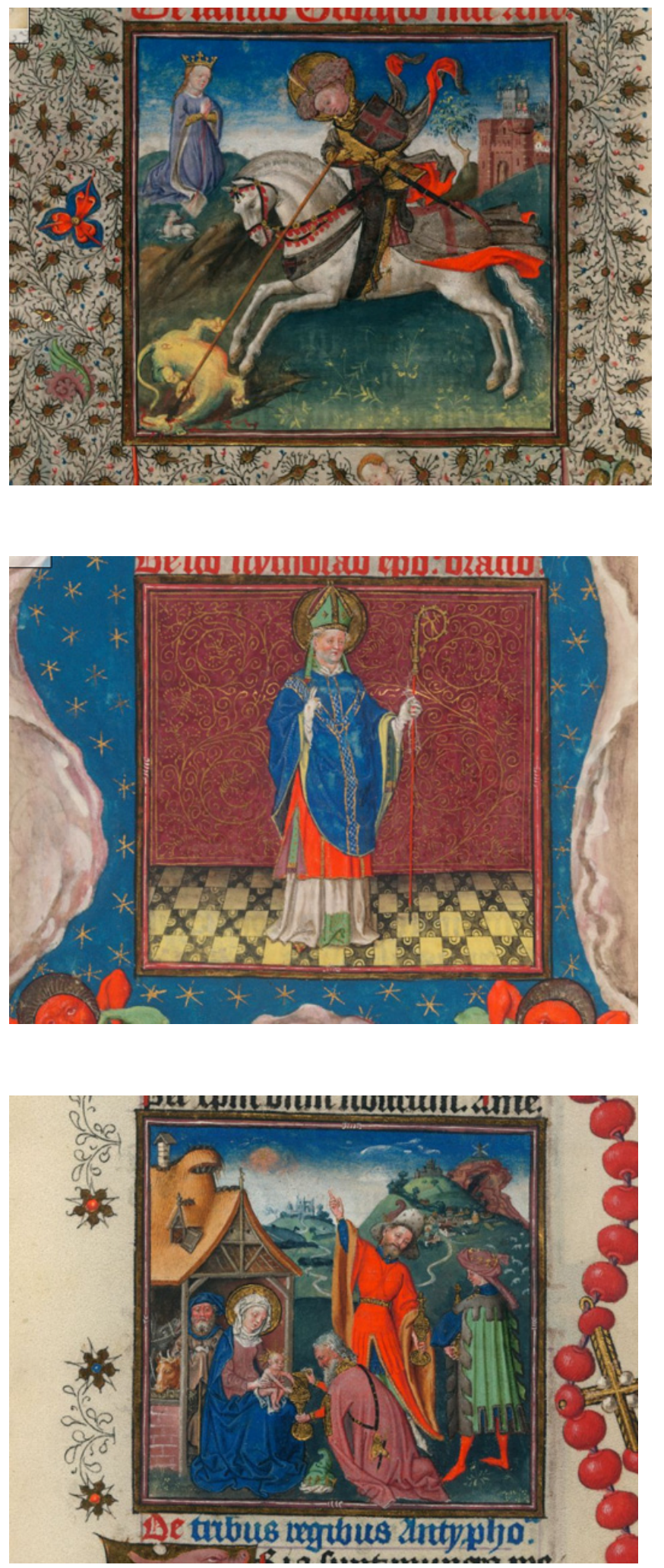

St George and the Dragon (and Virginity).

\section{St Nicholas.}

Bishop of Myra (in modern day Turkey). Upon hearing that a local man had fallen on such hard times that he was planning to sell his daughters into prostitution, Nicholas went by night to the house and threw three bags of gold in through the window, saving the girls from an evil life. These three bags, gold generously given in time of trouble, became the three golden balls that indicate a pawn broker's shop.

During a voyage to the Holy Lands, a fierce storm blew up, threatening the ship. He prayed over it, and the storm calmed. Hence he is the patron of those who travel by sea. Feast December 6 .

\section{The adoration of the magi.}

This narrative scene, which interrupts the series of pictures of saints, precedes the suffrage for the Three Kings. With no sign of their entourage, the kings approach from the right; they are expensively and fashionably dressed, and each carries a gold ciborium-like vessel. The first king, his tall-crowned hat on the ground before him, kneels in front of the Child, offering him gold; the second king points to the distant star; and the third and youngest stands waiting his turn. The plainly dressed Virgin sits at the entry to the stable holding her Infant on her knees; behind her, inside the stable, sits a stolid and rather plebeian Joseph, his hands upon his staff. Beside him are the unruly ass and an ox eating from the manger. In the distance is a cool green landscape with a village, a windmill and castles. Disposed around the page is Catherine of Cleves' red-beaded rosary, terminated by tassels with gold and pearls. Attached to the rosary are a seven-pointed star of pearls and gold, a small cross of the same materials, and a blue purse with drawstrings, a gold mouth, and three red tassels drawn through pearls. The purse bears the letters $C D$, or possibly ED, in gold encrusted with pearls (Catherina Duxissa?) 


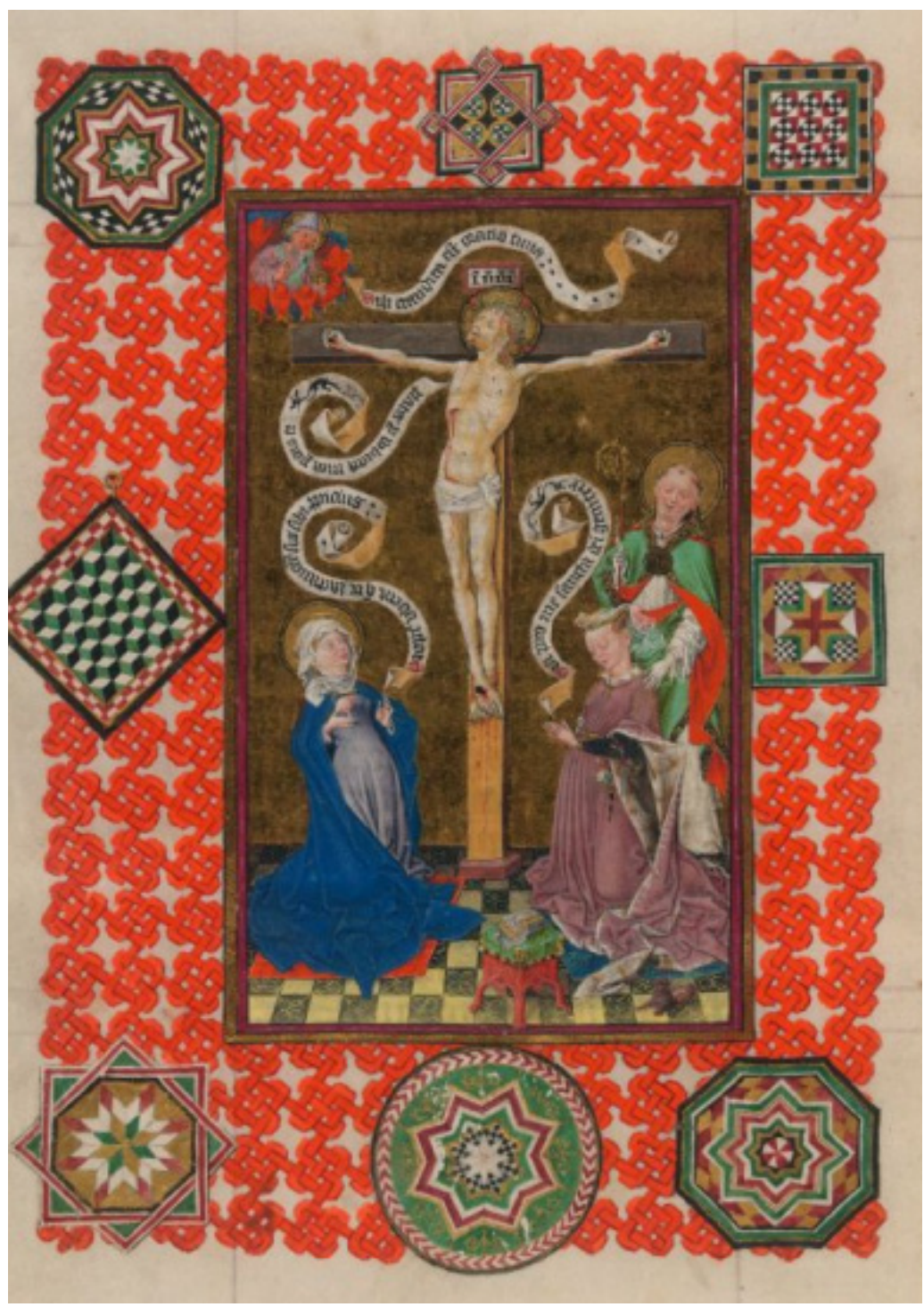

\section{The Crucifixion.}

The significance of this devotional scene is explained by the banderoles: Catherine pleads with the Holy Mother of God to pray for her; the Virgin intercedes with her Son to be gracious to Catherine for His mother's sake, whose breasts nursed Him; Christ crucified asks, in the name of His wounds, for His Father to spare Catherine; and the Father tells His Son, "Your prayer has been heard with favour."

On the tiled floor at either side of the cross, kneel the Virgin (on a red carpet) to the left, and Catherine (on a blue carpet) to the right. The Virgin, one of her breast bare and spurting milk, gazes up at her Son; Catherine looks down at her praying hands and carries over her arm the rosary that we have seen before. She wears a mauve-rose, ermine-lined houppelande, and her hair is worn in pointed templers under a goffered veil. On the floor in front of her are a tiny poodle-like dog and beautifully painted stool with a half-open book on it. Behind her stands an unidentified saint with a crozier, presumably a bishop and her patron saint, who gently touches her shoulder with his gloved hand. The Christ is not dead, but rather looks up beseechingly to His Father, who appears in the corner surrounded by angels, wearing a tiara, holding a globe and blessing his Son. The miniature is surrounded by an elaborate pattern of orange interlace knots upon which are hung panels of geometrical intarsia work, Italian or Spanish in style.

This scene sums up for me the Medieval approach to Godthoroughly hierarchical and very "bodily"-you approach the heavenly court with your patron. You do not approach directly, you go through intermediaries, people you can expect to be "friends at court". Catherine approaches Jesus by way of Mary. Mary uses a potent symbol of her status with respect to her son-her breast-milk. Jesus conveys the prayer to God the Father backed by the blood of his wounds. Catherine's prayers were heard with favour and I hope you have looked favourably on their inspiration today. a 